\title{
Model Penentuan Nilai Target Functional Requirement Berbasis Utilitas
}

\author{
Cucuk Nur Rosyidi ${ }^{*}$
}

\begin{abstract}
In a product design and development process, a designer faces a problem to decide functional requirement (FR) target values. That decision is made under a risk since it is conducted in the early design phase using incomplete information. Utility function can be used to reflect the decision maker attitude towards the risk in making such decision. In this research, we develop a utility-based model to determine FR target values using quadratic utility function and information from Quality Function Deployment (QFD). A pencil design is used as a numerical example using quadratic utility function for each FR. The model can be applied for balancing customer and designer interest in determining FR target values.
\end{abstract}

Keywords: Optimization, quadratic utility, risk, functional requirement.

\section{Pendahuluan}

Sebuah produk dirancang dan dikembangkan untuk memenuhi kebutuhan dan keinginan pelanggan. Produk tersebut harus dibuat dengan tetap menjaga kualitas pada biaya yang kompetitif. Quality Function Deployment (QFD) banyak digunakan untuk membantu perancangan, pengembangan, dan perbaikan produk berdasarkan voice of customer (Fung et al. [3]). Tujuannya adalah memberikan kepuasan kepada pelanggan. Metodologi tersebut telah diimplementasikan dalam banyak bidang meliputi kesehatan, pendidikan, perangkat lunak, konstruksi, dan industri pesawat terbang (Kumar et al. [10]). Konsep dasar QFD adalah menerjemahkan customer requirement (CR) ke dalam technical attributes (TA) atau engineering chracteristics (Fung et al. [3]). Dalam hal ini, van de Poel [19] menyatakan bahwa dalam QFD, para peneliti menggunakan istilah yang berbeda-beda dalam menyatakan $\mathrm{CR}$ dan TA. Dalam penelitian ini digunakan istilah functional requirement (FR) untuk menyatakan TA seperti dalam El-Haik [2]. FR adalah requirement independen minimum yang secara lengkap mencirikan kebutuhan fungsional sebuah produk (Suh, [16]). Secara umum terdapat dua tujuan dalam implementasi $Q F D$, yaitu penentuan prioritas $C R$ atau FR dan penentuan nilai target FR (Rosyidi et al. [14]).

Dalam penelitian ini dikembangkan model penentuan nilai target FR berbasis utilitas menggunakan fungsi utilitas kuadratik memanfaatkan informasi yang diperoleh dari matriks QFD. Dalam menentukan nilai target FR, desainer dihadapkan pada masa-

1 Fakultas Teknik, Jurusan Industri, Universitas Sebelas Maret Surakarta. Jl. Ir. Sutami 36A, Surakarta 57126, Indonesia.

Email: cucuk@uns.ac.id

* Penulis korespondensi lah pengambilan keputusan beresiko. Resiko tersebut disebabkan karena sebagian besar keputusan yang diambil dalam desain rekayasa dibuat menggunakan model yang tidak sempurna, informasi yang tidak presisi, dan pengetahuan yang terbatas (Gurnani dan Lewis [4]). Keputusan yang diambil terkait dengan nilai target FR akan menentukan nilai produk dalam pandangan pelanggan. Selain itu, desainer juga menghadapi ketidakpastian tentang waktu dan biaya yang dibutuhkan dalam perancangan produk. Sikap desainer terhadap resiko yang disebabkan oleh ketidakpastian tersebut dapat dinyatakan dengan fungsi utilitas. Demikian juga halnya dengan pelanggan yang menghadapi ketidakpastian tentang nilai produk yang sedang dirancang dalam pandangan mereka.

Karakteristik beberapa penelitian tentang penentuan nilai target FR secara ringkas dapat dilihat pada Tabel 1. Penelitian tentang penentuan nilai target FR yang memaksimumkan utilitas desainer telah dilakukan antara lain oleh Locascio dan Thurston [12] dan Yeh et al. [21]. Askin dan Dawson [1] mengembangkan model penentuan nilai target FR untuk memaksimumkan nilai produk dalam pandangan pelanggan. Dengan biaya dan waktu yang terbatas, memaksimumkan utilitas desainer atau pelanggan akan menghasilkan sebuah desain dengan nilai target FR masing-masing pada titik terendah atau tertingginya. Diperlukan sebuah pendekatan yang dapat mengakomodasi kepentingan desainer dan pelanggan dalam penentuan nilai target FR. Lin dan Wei [11] mengintegrasikan nilai pengaruh fitur produk bagi pelanggan dan desainer dalam pemilihan perbaikan desain produk. Dalam penelitian tersebut, nilai produk didefinisikan oleh pelanggan dan desainer masing-masing menggunakan atribut dan karakteristik produk. Penelitian tersebut tidak menggunakan fungsi utilitas dalam 
Tabel 1. Karakteristik model

\begin{tabular}{|c|c|c|c|c|}
\hline Peneliti & Tujuan model & Fungsi tujuan & Kendala & Linear/Nonlinear \\
\hline $\begin{array}{l}\text { Locascio dan Thurston } \\
\text { [12] }\end{array}$ & $\begin{array}{l}\text { Penentuan nilai target } \\
\text { FR }\end{array}$ & $\begin{array}{l}\text { Maksimasi utilitas } \\
\text { desainer }\end{array}$ & Fungsi transfer FR-DP & Nonlinear \\
\hline Askin dan Dawson [1] & $\begin{array}{l}\text { Penentuan nilai target } \\
\text { FR }\end{array}$ & $\begin{array}{l}\text { Maksimasi nilai produk } \\
\text { bagi pelanggan }\end{array}$ & $\begin{array}{l}\text { Biaya, waktu, dan } \\
\text { kesulitan teknikal dalam } \\
\text { desain }\end{array}$ & Nonlinear \\
\hline Yeh et al. [21] & $\begin{array}{l}\text { Penentuan nilai target } \\
\text { FR }\end{array}$ & $\begin{array}{l}\text { Maksimasi utilitas } \\
\text { pengambil keputusan } \\
\text { dalam desain }\end{array}$ & $\begin{array}{l}\text { Indikator konsensus antar } \\
\text { pengambil keputusan }\end{array}$ & Nonlinear \\
\hline Lin dan Wei [11] & $\begin{array}{l}\text { Pemilihan alternatif } \\
\text { perbaikan desain }\end{array}$ & $\begin{array}{l}\text { Maksimasi nilai pengaruh } \\
\text { bagi pelanggan dan } \\
\text { desainer }\end{array}$ & Waktu dan biaya & Linear \\
\hline Penelitian ini & $\begin{array}{l}\text { Penentuan nilai target } \\
\text { FR }\end{array}$ & $\begin{array}{l}\text { Minimasi gap utilitas } \\
\text { pelanggan dan desainer }\end{array}$ & $\begin{array}{l}\text { Waktu dan biaya, dan } \\
\text { fungsi transfer biaya-nilai } \\
\text { target. }\end{array}$ & Nonlinear \\
\hline
\end{tabular}

merepresentasikan nilai produk dan model yang dikembangkan tidak digunakan untuk menentukan nilai target FR.

Penentuan nilai target FR penting dilakukan karena akan menentukan nilai sebuah produk. Fungsi utilitas adalah sebuah cara untuk merepresentasikan nilai produk yang dapat mengakomodasi ketidakpastian dan risiko dalam penentuan nilai target FR. Dalam penelitian ini dikembangkan sebuah model optimisasi yang digunakan untuk menentukan nilai target FR dengan mengintegrasikan fungsi utilitas desainer dan pelanggan ke dalam satu fungsi tujuan untuk meminimasi gap di antara keduanya. Integrasi tersebut diharapkan dapat menyelesaikan masalah pengambilan keputusan tentang besaran nilai target FR, tidak hanya dari sudut pandang desainer, tetapi juga pelanggan. Model yang dikembangkan akan mempertimbangkan waktu, biaya dan kesulitan teknikal dalam perancangan produk.

\section{Metode Penelitian}

\section{Fungsi Utilitas dan Desain Rekayasa}

Fungsi utilitas menyatakan sikap seorang pengambil keputusan terhadap risiko yang ditimbulkan oleh ketidakpastian terhadap hasil suatu pilihan keputusan. Dalam hal ini, pengambil keputusan dihadapkan pada beberapa alternatif keputusan yang dapat dinyatakan sebagai alternative $A_{j}, j=$ $1,2, \ldots, J$. Setiap alternatif memunculkan even tertentu, dan setiap even menghasilkan konsekuensi tertentu. Terkait dengan konsekuensi, Raiffa [13] menyatakan bahwa terdapat preferensi kondisional dan preferensi independen. Pada preferensi kondisional, Keeney [7] memberikan contoh sebagai berikut: misalnya pengambil keputusan dihadapkan pada tiga konsekuensi $(x, y, z)$, sedemikian sehingga $x_{0} \leq x \leq x^{*}, y_{0} \leq y \leq y^{*}, z_{0} \leq z \leq z^{*}$. Jika nilai $z$ ditetapkan pada angka tertentu $z^{\prime}$, maka jika pengambil keputusan lebih memilih konsekuensi $\left(x_{1}, y_{1}, z^{\prime}\right)$ dibandingkan dengan $\left(x_{2}, y_{2}, z^{\prime}\right)$ maka dapat dinyatakan bahwa $\left(x_{1}, y_{1}\right)$ lebih dipilih secara kondisional dibandingkan dengan $\left(x_{2}, y_{2}\right)$ pada nilai $z^{\prime}$. Sedangkan preferensi independen dapat dibagi menjadi dua, yaitu weak conditional utility independence (WCUI) yang kemudian dikenal sebagai preferentially independent dan strong conditional utility independent (SCUI) yang kemudian dikenal sebagai utility independence. $X$ dan $Y$ disebut independen secara preferensial terhadap $Z$ jika $\left(x_{1}, y_{1}, z^{\prime}\right)$ lebih dipilih dibandingkan $\left(x_{2}, y_{2}, z^{\prime}\right)$ pada nilai $z^{\prime}$, maka $\left(x_{1}, y_{1}, z^{\prime \prime}\right)$ juga akan lebih dipilih dibandingkan dengan $\left(x_{2}, y_{2}, z^{\prime \prime}\right)$ pada sembarang nilai $z^{\prime \prime} . X$ disebut sebagai utility independent, terhadap $Y$ dan $Z$, jika $\left(y^{\prime}, z^{\prime}\right)$ dan distribusi probabilitasnya yang dinyatakan oleh $p_{1}(x, y, z)$ lebih dipilih dibandingkan dengan $\left(y^{\prime \prime}, z^{\prime \prime}\right)$ dan distribusi probabilitasnya $p_{2}(x, y, z)$, maka preferensi yang sama akan berlaku untuk sembarang nilai $Y$ dan $Z$.

Keeney dan Raiffa [9] menyatakan bahwa fungsi utilitas bisa dalam bentuk monotonik dan nonmonotonik (misalnya pada fungsi utilitas kuadratik). Fungsi utilitas monotonik dapat dibagi menjadi dua, yaitu monotonik menaik dan menurun. Dalam hal tersebut terdapat beberapa sikap dasar pengambil keputusan terhadap risiko yaitu risk averse, neutral dan risk prone. Fungsi utilitas untuk ketiga sikap tersebut masing-masing berbentuk concave, linear dan convex dimana masing-masing dapat menaik, konstan atau menurun seperti terlihat pada Gambar 1.

Desain rekayasa dapat dianggap sebagai sebuah permasalahan proses pengambilan keputusan. Menurut Takai dan Ishii [17], permasalahan pengambilan keputusan memerlukan tiga komponen yaitu pilihan, informasi, dan preferensi. Pilihan adalah alternatif yang dihadapi oleh pengambil 
keputusan. Informasi adalah pemodelan terhadap permasalahan pengambilan keputusan dan penilaian terhadap ketidakpastian, sedangkan preferensi dapat dinyatakan menggunakan fungsi utilitas. Fungsi utilitas merupakan representasi preferensi pengambil keputusan, maka fungsi utilitas memberikan dua tujuan penting dalam desain rekayasa (Scott [15]). Pertama, fungsi utilitas memungkinkan desainer untuk membangun satu fungsi tujuan yang melibatkan seluruh atribut yang dipertimbangkan dalam desain dan menyatukannya ke dalam satu skala. Kedua, fungsi tujuan yang dibangun didasarkan pada hasil setiap alternatif yang dinyatakan sebagai distribusi probabilitas.

Dalam pengembangan dan perancangan produk, fungsi utilitas dapat digunakan untuk mentransfer nilai tujuan desain ke dalam tingkat kepuasan kebutuhan pelanggan menggunakan formulasi matematik (Yang et al. [20]). Selain itu, fungsi utilitas juga dapat digunakan untuk menyatakan nilai sebuah produk dalam pandangan pelanggan. Askin dan Dawson [1] menyatakan bahwa terdapat perbedaan antara keduanya (nilai dan utilitas).

Fungsi nilai mengasumsikan kejadian tanpa risiko (probabilitas kejadian=1), sedangkan dalam fungsi utilitas terdapat ketidakpastian dalam hal hasil (probabilitas <1). Meskipun demikian, Keeney dan Raiffa [9] menyatakan bahwa fungsi utilitas adalah fungsi nilai, sebaliknya fungsi nilai tidak selalu merupakan fungsi utilitas. Penelitian Askin dan Dawson [1] dilakukan dengan fungsi tujuan maksimasi nilai produk bagi pelanggan tidak menggunakan fungsi utilitas, tetapi menggunakan fungsi nilai yang diperoleh dengan menggunakan normalisasi. Normalisasi dilakukan dengan memetakan nilai minimum dan maksimum nilai target FR ke dalam selang nilai antara nol dan satu. Penelitian tersebut memperhatikan kendala-kendala biaya, waktu dan kesulitan teknikal dalam pengembangan dan perancangan produk.

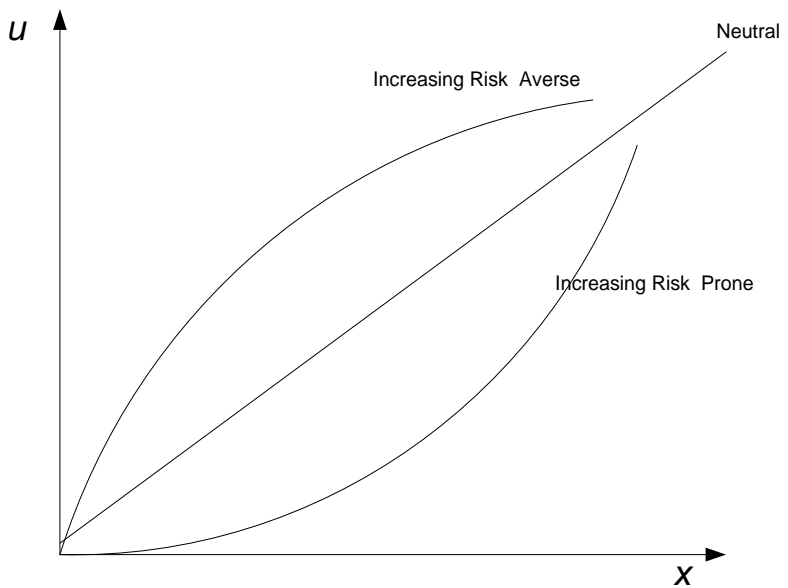

Gambar 1. Fungsi utilitas risk averse, neutral dan risk prone
Gurnani dan Lewis [4] mengembangkan model pengambilan keputusan dengan mempertimbangkan risiko dan ketidakpastian dalam desain rekayasa. Dalam penelitian tersebut, digunakan metode ekuivalen dan inekuivalen hipotetik, yang hasil metode tersebut digunakan sebagai dasar pembentukan model sebenarnya. Penelitian tersebut memasukkan fungsi utilitas dalam model dengan asumsi setiap kriteria independen. Locascio dan Thurston [12] menggunakan utilitas multiatribut untuk melakukan formulasi optimisasi multiobjective terhadap QFD. Fungsi tujuannya adalah maksimasi utilitas dengan memperhatikan kendalakendala yang persamaannya diturunkan dari QFD dan hukum alam. Pendekatan yang dilakukan adalah mengintegrasikan tujuan yang didefinisikan secara kualitatif oleh konsumen dengan tujuan yang ditetapkan oleh desainer secara kuantitatif dalam satu model optimisasi. Penelitian tersebut mengasumsikan bahwa setiap CR memiliki ukuran kuantatif dengan metrik tertentu sesuai dengan konteksnya. Sedangkan pada kenyataannya, kebanyakan CR tidak memiliki metrik. Hal ini menyebabkan sifat kualitatif QFD tidak dapat dihilangkan dalam pemodelan utilitas multi atribut dengan memberikan bobot pada setiap FR.

Lin dan Wei [11] mengembangkan model optimisasi untuk pemilihan perbaikan desain produk menggunakan programa linear. Fungsi tujuannya adalah maksimasi nilai pengaruh fitur produk pelanggan dan desainer. Dalam penelitian tersebut fitur produk menyatakan atribut dan karakteristik produk masing-masing bagi pelanggan dan desainer. Atribut produk adalah bagian pelanggan dalam menyatakan sebuah produk, sedangkan karakteristik merupakan aspek fungsional produk yang menjadi bagian desainer. Model dalam penelitian tersebut menggunakan kendala biaya dan waktu yang disediakan perusahaan dalam perbaikan desain produk. Selain itu digunakan pembobotan dalam fungsi tujuan untuk memberikan nilai yang berbeda bagi pelanggan dan desainer dimana semakin besar bobot pelanggan menunjukkan produk yang semakin berorientasi pada pelanggan.

\section{Pemodelan}

Model yang digunakan dalam penelitian ini adalah model yang dikembangkan oleh Rosyidi et al. [14]. Pada penelitan tersebut, fungsi utilitas yang digunakan adalah eksponensial, sedangkan penelitian ini menggunakan fungsi utilitas kuadratik. Fungsi utilitas eksponensial mengasumsikan bahwa utilitas pengambil keputusan akan naik atau turun secara monotonik tergantung pada karakteristik FR. Pada kasus larger the better, fungsi utilitas pelanggan akan naik secara monotonik dengan semakin tinggi- 
nya nilai target FR, sedangkan fungsi utilitas desainer akan menurun secara monotonik karena semakin tinggi nilai target FR membutuhkan biaya desain yang semakin tinggi. Fungsi utilitas kuadratik mengasumsikan bahwa utilitas pengambil keputusan akan naik secara monotonik hingga mencapai nilai 1 pada nilai target FR tertentu, kemudian menurun secara monotonik. Contohnya pada kasus FR panjang pensil, nilai utilitas akan menaik sampai pada satuan panjang tertentu kemudian menurun pada nilai satuan yang lebih panjang. Hal ini disebabkan karena panjang pensil menentukan kenyamanan pelanggan dalam memegang dan menulis, sehingga tidak selalu semakin panjang pensil akan menaikkan utilitas pelanggan. Pada panjang tertentu, nilai utilitas pelanggan akan mencapai puncaknya dan akan menurun pada nilai panjang setelahnya.

\section{Fungsi Tujuan}

Fungsi tujuan model dalam penelitian ini adalah minimasi gap antara utilitas pelanggan dan desainer dalam menentukan nilai target FR seperti dinyatakan dalam persamaan (1). Pada persamaan tersebut, $w_{j}$ menyatakan bobot setiap FR yang dapat diperoleh dari QFD. $U_{j}^{k}\left(y_{j}\right)$ menyatakan utilitas pelanggan untuk FR ke-j, sedangkan $U_{j}^{d}\left(z_{r j}\right)$ menyatakan fungsi utilitas desainer untuk FR ke-j. Pada penelitian ini digunakan fungsi utilitas kuadratik dan diasumsikan bahwa utilitas desainer mengikuti bentuk fungsi utilitas pelanggan. Bentuk umum fungsi utilitas kuadratik yang digunakan dalam penelitian ini seperti pada persamaan (2).

Pada desainer tunggal, fungsi utilitas dapat diperoleh dengan menanyakan secara langsung sikap desainer terhadap nilai target FR. Sedangkan pada kasus lebih dari satu desainer (kelompok) dapat digunakan metode participatory groups dimana para desainer membuat konsensus dalam proses penentuan distribusi probabilitas untuk merepresentasikan sikap mereka terhadap nilai target FR (Keeney dan Raiffa [9]). Fungsi utilitas pelanggan dapat ditentukan dengan metode participatory groups (Keeney dan Raiffa [9]) dan survei (Hauser dan Urban [5]). Pada metode survei, perusahaan dapat menanyakan utilitas pelanggan tentang beberapa nilai FR dalam rentang yang telah ditentukan. Menurut Scott [15] metode curve fitting secara manual maupun numerik dapat digunakan untuk menurunkan parameter fungsi utilitas. Setelah itu, parameter fungsi utilitas dapat ditentukan menggunakan rataan parameter fungsi utilitas seluruh pelanggan (Hauser dan Urban [5]), distribusi probabilitas parameter pelanggan untuk meng- atasi heterogenitas (Keeney dan Lilien [8]), atau persentase terbesar pernyataan terpilih (Kahneman dan Tversky [6]). Secara lebih rinci, penurunan parameter fungsi utilitas dapat dilihat pada penelitian Thevenot et al. [18].

$\operatorname{Min} \sum_{j=1}^{J} w_{j}\left|U_{j}^{k}\left(y_{j}\right)-U_{j}^{d}\left(z_{r j}\right)\right|$

$U(y)=-b y^{2}+c y+d$

Nilai $w_{j}$ dapat diperoleh dari matriks QFD dengan menggunakan persamaan (3). Pada persamaan tersebut, $w_{i j}$ menyatakan bobot hubungan antara CR ke-i dengan FR ke-j.

$w_{j}=\frac{\sum_{i=1}^{I} w_{i j}}{\sum_{j=1}^{J} \Sigma_{i=1}^{I} w_{i j}}$

Utilitas desainer terdiri dari dua fungsi yaitu biaya dan waktu, maka perlu dilakukan penentuan konstanta skala agar kedua fungsi tersebut menghasilkan nilai $(0,1]$. Dengan asumsi preferensi dan utilitas independen maka utilitas desainer dapat dinyatakan sebagai berikut (Locascio dan Thurston [12]):

$U_{j}^{d}\left(z_{r j}\right)=\frac{1}{K_{j}}\left\{\prod_{r=1}^{2}\left[K_{j} a_{r j} U_{j}^{d}\left(z_{r j}\right)+1\right]-1\right\}$

dimana $K$ menunjukkan skala normalisasi, $a_{r j}$ menyatakan konstanta skala ke-r untuk FR ke-j , sedangkan $U_{j}^{d}\left(z_{r j}\right)$ menunjukkan utilitas desainer terkait dengan biaya (untuk $r=1$ ) dan waktu (untuk $r=2$ ). Nilai $K$ dapat diperoleh dengan menggunakan persamaan (5) (Keeney dan Raiffa [9]).

$1+K=\prod_{r=1}^{2}\left(1+K a_{r j}\right)$

Jika pada persamaan (4) $\sum_{r=1}^{2} a_{r j}=1$ maka persamaan tersebut akan menjadi bentuk aditif yang lebih sederhana seperti pada persamaan (6) (Keeney dan Raiffa [9]).

$U_{j}^{d}\left(z_{j}\right)=\sum_{r=1}^{2} a_{r j} U_{j}^{d}\left(z_{r j}\right)$

\section{Kendala}

Kendala yang diperlukan dalam model penentuan nilai target FR ini adalah sebagai berikut:

Batas atas dan bawah nilai target FR seperti dinyatakan oleh persamaan (7). Nilai batas tersebut diperoleh dari matriks competitive assesment QFD dengan asumsi bahwa kapabilitas teknologi perusahaan manufaktur tidak dapat menghasilkan nilai target FR yang lebih tinggi dari nilai batas atas atau lebih rendah dari nilai batas bawah masingmasing untuk kasus larger the better dan lower the better. Pada persamaan (7), $y_{j}^{l}$ dan $y_{j}^{u}$ masingmasing menyatakan batas bawah dan batas atas nilai target FR. 
$y_{j}^{l} \leq y_{j} \leq y_{j}^{u}$

Anggaran dana dan waktu yang disediakan oleh perusahaan manufaktur dalam desain produk. Secara umum, kedua kendala tersebut dapat dinyatakan dalam persamaan (8). Dalam persamaan tersebut, $z_{r j}$ menyatakan biaya atau waktu yang diperlukan dalam perancangan produk untuk FR ke- $j$, sedangkan $z_{r}^{u}$ menyatakan batas atas waktu atau biaya yang disediakan dalam perancangan produk.

$\sum_{i=1}^{J} z_{r j} \leq z_{r}^{u}$

Biaya dan waktu yang diperlukan dalam desain sebagai fungsi dari nilai target FR, seperti dinyatakan dalam persamaan (9). Persamaan tersebut diperlukan agar desainer dan pelanggan berada dalam domain yang sama yaitu nilai target FR sehingga utilitas keduanya dapat dibandingkan.

$z_{r j}=f\left(y_{j}\right), \forall r$

Total bobot yang digunakan pada persamaan (1) harus sama dengan satu, dapat dinyatakan dengan persamaan (10)

$\sum_{j=1}^{J} w_{j}=1$

Dengan demikian maka model optimisasi penentuan nilai target FR dapat dinyatakan sebagai berikut:

$\operatorname{Min} \sum_{j=1}^{J} w_{j}\left|U_{j}^{k}\left(y_{j}\right)-U_{j}^{d}\left(z_{r j}\right)\right|$

dengan memperhatikan

$y_{j}^{l} \leq y_{j} \leq y_{j}^{u}$

$\sum_{i=1}^{J} z_{r j} \leq z_{r}^{u}$

$z_{r j}=f\left(y_{j}\right), \forall r$

$z_{r j}=f\left(y_{j}\right), \forall r$

$\sum_{j=1}^{J} w_{j}=1$

\section{Hasil dan Pembahasan}

Penelitian ini menggunakan contoh numerik desain pensil yang diadaptasi dari penelitian Askin dan Dawson [1]. QFD untuk desain pensil tersebut dapat dilihat pada Gambar 2. Terdapat tiga CR dalam desain pensil meliputi Easy to hold, Does not smear, dan Point lasts yang kemudian diterjemahkan oleh desainer menjadi tiga FR yaitu panjang pensil (dalam satuan inchi), waktu antar perautan (dalam satuan halaman), dan debu yang dihasilkan oleh inti pensil (dalam satuan $\mathrm{mg} / \mathrm{cm}^{2}$ ). Setiap CR diberi bobot yang diperoleh dari Voice of Customer, yang dalam penelitian ini untuk masing-masing CR diberikan bobot 4, 5, dan 3. Hubungan antara CR dengan FR dinyatakan secara kualitatif yang terdiri dari tiga tingkatan yaitu lemah, kuat, dan sangat kuat yang dikuantifikasikan masing-masing dengan nilai 1, 3, dan 9. Dalam penelitian ini diasumsikan terdapat empat produk pesaing yaitu Produk A, B, C, dan D dengan nilai target setiap FR seperti terlihat pada bagian bawah matriks QFD pada Gambar 2. Cost factors menunjukkan biaya desain yang diperlukan untuk setiap satu unit FR. Sebagai contoh, cost factor untuk $\mathrm{FR}_{2}$ adalah sebesar 2 satuan mata uang yang berarti bahwa biaya desain untuk satu unit FR tersebut adalah 2.

Fungsi utilitas pelanggan dapat diturunkan dengan meminta pelanggan memberikan nilai utilitas terhadap nilai target FR produk. Nilai target FR yang digunakan didasarkan pada nilai target FR produk pesaing. Dengan menggunakan fungsi utilitas kuadratik maka pada kasus larger the better fungsi utilitas pelanggan akan naik secara monotonik hingga pada satu nilai FR tertentu. Setelah itu fungsi utilitasnya akan menurun secara monotonik dengan menurunnya nilai target FR. Pada kasus ini, perusahaan harus mengeluarkan biaya yang semakin besar dengan semakin tingginya nilai target FR, sehingga fungsi utilitas desainer akan naik secara monotonik hingga pada tingkat biaya tertentu. Setelah itu, fungsi utilitasnya akan menurun secara monotonik dengan semakin tingginya biaya desain hingga mencapai nilai utilitas nol pada biaya desain maksimum. Dengan menggunakan persamaan (2) sebagai bentuk umum fungsi utilitas kuadratik pelanggan dan desainer, maka grafik fungsi utilitas keduanya untuk setiap FR dalam contoh numerik ini dapat dilihat pada Gambar 3. Dengan asumsi total biaya maksimum yang disediakan perusahaan sebesar 20 unit satuan mata uang, maka model penentuan nilai target FR untuk contoh numerik dalam penelitian ini dapat dinyatakan seperti pada persamaan (12). Pada persamaan tersebut, bobot untuk setiap FR masing-masing adalah sebesar 0,359, 0,314, dan 0,327 yang diperoleh dengan menggunakan persamaan (3).

$$
\begin{aligned}
& \text { Min } 0,359 \mid\left(\frac{-1}{3} y_{1}^{2}+3,83 y_{1}-10.002\right)-\left(0,367 y_{1}^{2}+\right. \\
& \left.3,554 y_{1}-7,604\right)|+0,314|\left(-0,257 y_{2}^{2}+2,328 y_{2}-\right. \\
& 4,272)-\left(\frac{-12}{70} y_{2}^{2}+1,228 y_{2}-1,199\right) \mid+ \\
& 0,327 \mid\left(-0,483 y_{3}^{2}+2,473 y_{3}-2,165\right)-\left(-0,632 y_{3}^{2}+\right. \\
& \left.4,114 y_{3}+5,695\right) \mid
\end{aligned}
$$

dengan memperhatikan

$$
\begin{aligned}
& 4 \leq y_{1} \leq 6,5 \\
& 2,5 \leq y_{2} \leq 6 \\
& 2 \leq y_{3} \leq 4 \\
& y_{1}+2 y_{2}-2 y_{3} \leq 11
\end{aligned}
$$

Hasil optimisasi model tersebut di atas dapat dilihat pada Tabel 2. Pada tabel tersebut dapat dilihat 


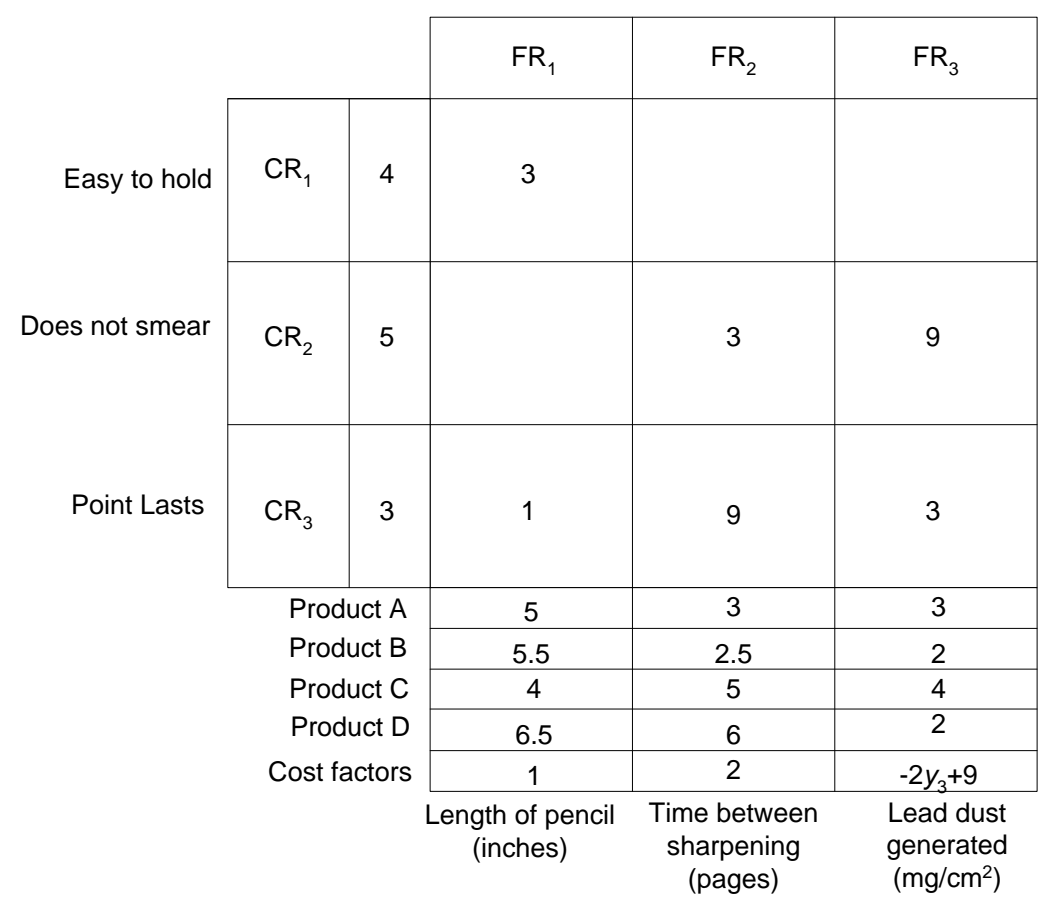

Gambar 2. Matriks QFD untuk desain pensil

$\mathrm{FR}_{1}$

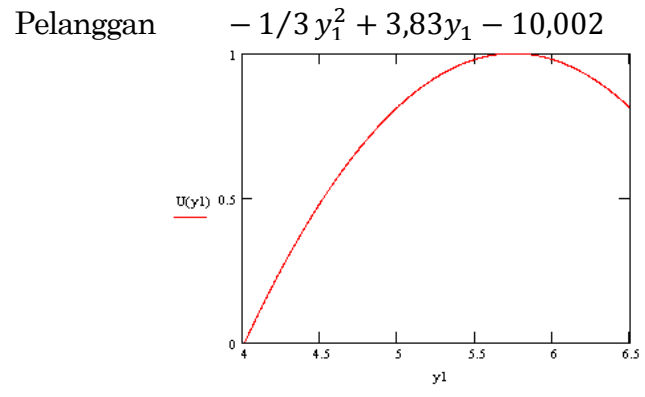

Desainer

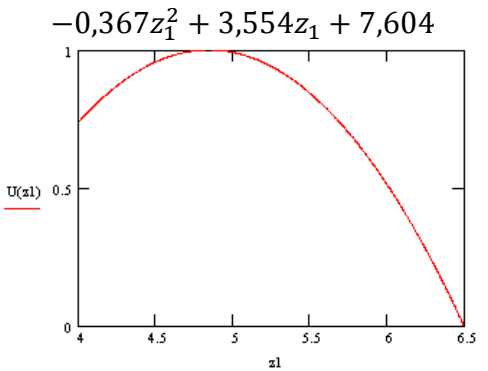

$\mathrm{FR}_{2}$
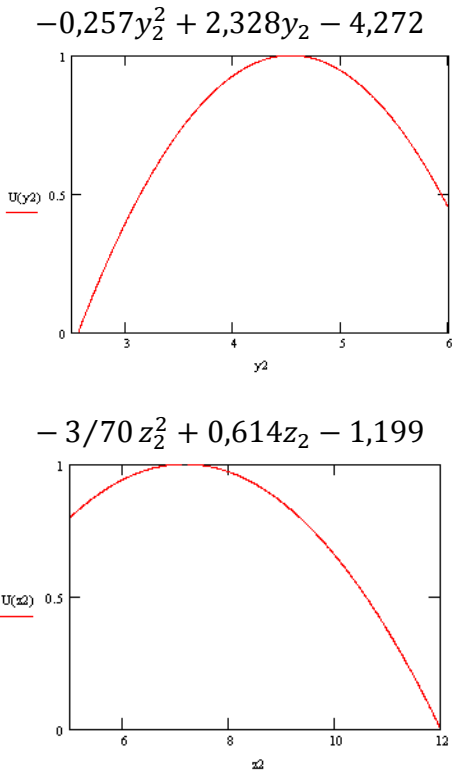

$\mathrm{FR}_{3}$
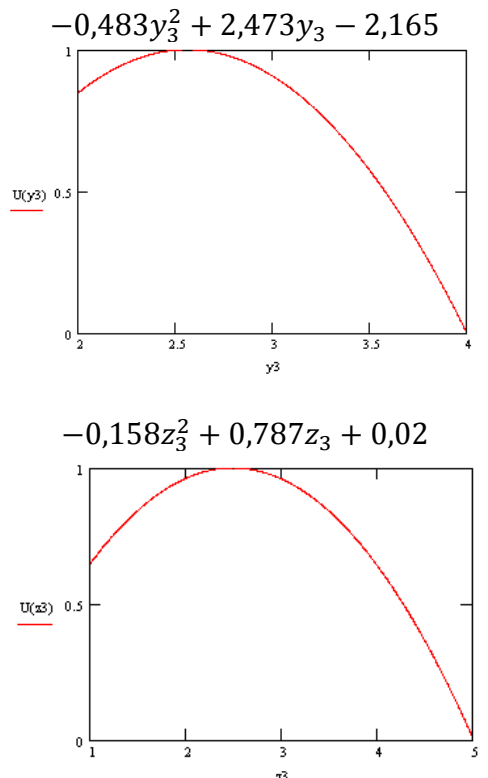

Gambar 3. Grafik fungsi utilitas pelanggan dan desainer untuk contoh numerik.

perbandingan nilai optimal model penelitian ini dengan model yang memaksimumkan utilitas pelanggan dan desainer. Maksimasi utilitas pelanggan dan desainer dapat dilakukan dengan menggunakan utilitas pelanggan dan desainer sebagai fungsi tujuan dengan kendala seperti pada persamaan (7) untuk pelanggan dan persamaan (7), (8), dan (9) untuk desainer. Nilai optimum model penelitian ini untuk setiap FR nilainya berada diantara model yang memaksimumkan utilitas pelanggan dan desainer. Hal ini menunjukkan bahwa model penelitian ini dapat digunakan untuk menyeimbangkan kepentingan pelanggan dan desainer dalam pengambilan keputusan tentang besaran nilai FR dalam proses perancangan dan pengembangan produk.

Dalam penelitian ini dilakukan analisis sensitivitas untuk mengetahui pengaruh parameter model terhadap variabel keputusan. Parameter yang akan dianalisis pengaruhnya adalah cost factor dan biaya maksimum yang disediakan oleh perusahaan dalam desain. Hasilnya dapat dilihat pada Gambar 4 (a), (b), dan (c) untuk cost factor dan Gambar 5 untuk biaya maksimum. Dari Gambar 4 (a) dan (b) dapat 
diketahui bahwa nilai FR cenderung menurun dengan semakin tingginya parameter cost factor pada FR yang mempunyai karakteristik larger the better $\left(y_{1}\right.$ dan $\left.y_{2}\right)$ dan cenderung naik pada FR yang mempunyai karakteristik smaller the better $\left(y_{3}\right)$. Sedangkan dari Gambar 5 dapat diketahui bahwa dengan semakin tingginya biaya desain yang disediakan perusahaan, nilai target FR semakin membaik. Hal ini disebabkan dengan bertambahnya biaya desain yang disediakan perusahaan, maka akan terdapat keleluasaan dalam menentukan nilai target FR pada nilai yang lebih baik. Meskipun demikian, terdapat batas maksimum biaya dimana penambahan biaya desain tidak akan memperbaiki nilai target FR.

Tabel 2. Perbandingan hasil optimisasi

\begin{tabular}{lccc}
\hline \multicolumn{1}{c}{ Model } & $y_{1}$ & $y_{2}$ & $y_{3}$ \\
\hline Model penelitian ini & 5,282 & 4,104 & 2,931 \\
Maksimasi utilitas pelanggan & 5,746 & 4,529 & 2,560 \\
Maksimasi utilitas desainer & 4,842 & 3,582 & 4,000 \\
\hline
\end{tabular}

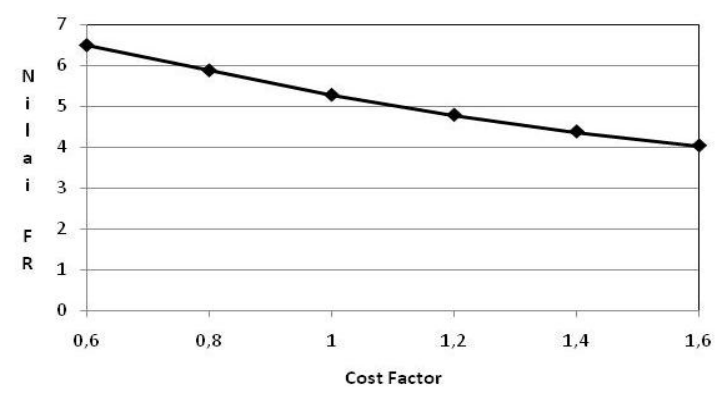

(a)

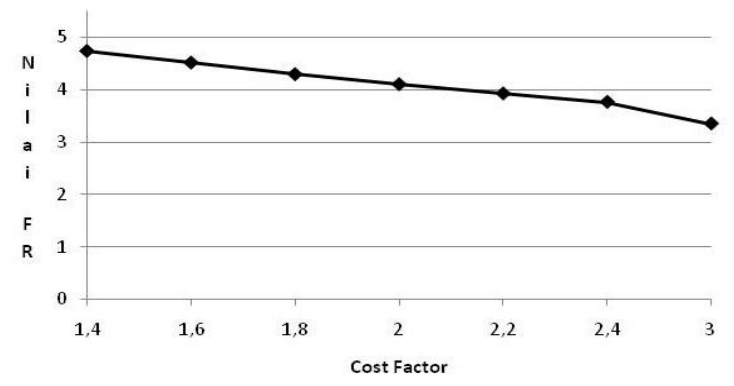

(b)

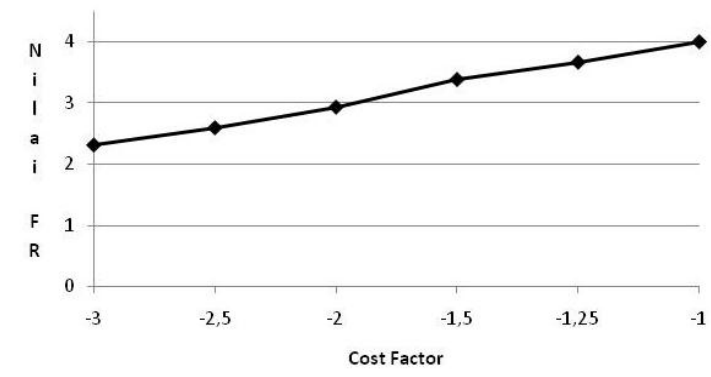

(c)

Gambar 4. Hasil analisis sensitivitas perubahan parameter cost factor (a) length of pencil, (b) time between sharpening, dan (c) lead dust generated

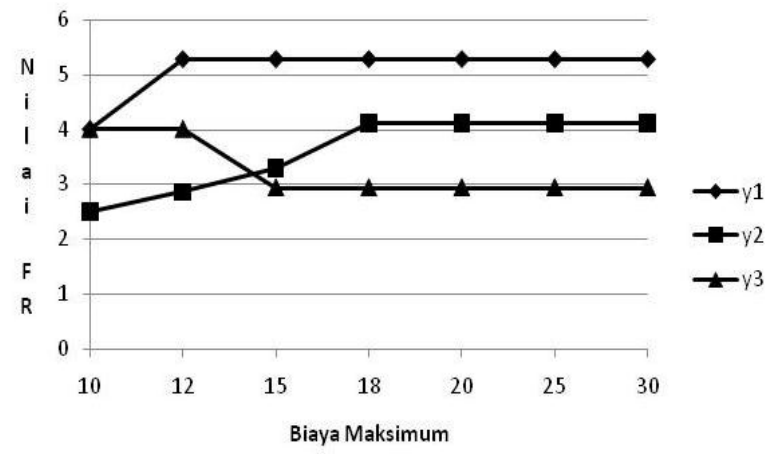

Gambar 5. Hasil analisis sensitivitas perubahan biaya maksimum yang disediakan perusahaan.

\section{Simpulan}

Dalam penelitian ini dijelaskan aplikasi fungsi utilitas kuadratik dalam penentuan nilai FR. Dalam desain rekayasa, fungsi utilitas dapat digunakan untuk menyatakan sikap pelanggan dan desainer dalam penentuan nilai target FR. Pada produk tertentu, fungsi utilitas terkait nilai target FR ini naik atau menurun secara monotonik hingga mencapai nilai tertentu dan menurun atau naik setelahnya. Fungsi utilitas yang merepresentasikan hal tersebut adalah fungsi utilitas kuadratik. Model dalam penelitian ini menggunakan fungsi utilitas kuadratik dalam pengambilan keputusan nilai target FR. Hasil optimisasi menunjukkan dengan menggunakan fungsi utilitas kuadratik, model dalam penelitian ini dapat menyeimbangkan kepentingan pelanggan dan desainer dalam penentuan nilai target FR. Analisis sensitivitas menunjukkan bahwa semakin besarnya parameter cost factor akan menyebabkan menurunnya nilai target FR dengan karakteristik larger the better dan menaiknya nilai target FR dengan karakteristik smaller the better. Penambahan biaya desain yang disediakan perusahaan akan menyebabkan nilai target FR membaik. Penelitian lanjutan dapat dilakukan dengan mengubah fungsi tujuan yang memungkinkan terjadi trade off antara biaya dan waktu yang dibutuhkan dalam desain serta di antara nilai FR. Selain itu model hasil penelitian ini juga dapat diimplementasikan dalam kasus nyata untuk mengetahui apakah pendekatan yang digunakan memberikan solusi yang lebih baik dibandingkan dengan pendekatan yang sudah ada.

\section{Daftar Pustaka}

1. Askin, R. G., and Dawson, D. W., Maximizing Customer Satisfaction by Optimal Specification of Engineering Characteristics, IIE Transactions, 32, 2000, pp. 9-20.

2. El-Haik, B., Axiomatic Quality: Integrating Axiomatic Design with Six-Sigma, Reliability, and Quality Engineering, John Wiley and Sons, 2005. 
3. Fung, R. Y. K., Tang, J., Tu, P. Y., and Chen, Y., Modeling of Quality Function Deployment Planning with Resource Allocation, Research in Engineering Design, 14, 2003, pp. 247-255.

4. Gurnani, A. P., and Lewis, K., Robust Multiattribute Decision Making under Risk and Uncertainty in Engineering Design, Engineering Optimization, 38(7), 2005, pp. 813-830.

5. Hauser, J. R., and Urban, G. L., Assessment of Attribute Importances and Consumer Utility Functions: von Neumann-Morgenstern Theory Applied to Consumer Behavior, The Journal of Consumer Research, Inc., 5, 1979, pp. 251-261.

6. Kahneman, D., and Tversky, A., Prospect Theory: An Analysis of Decision under Risk, Econometrica, 47(3), 1979, 263-292.

7. Keeney, R. L., Using Preferences for Multi-Attributed Alternatives, Journal of Multi-Criteria Decision Analysis, 14, 2006, pp. 169-174.

8. Keeney, R. L., and Lilien, G. L., A Utility Model for Product Positioning, Working Paper, MIT, 1975.

9. Keeney, R. L., and Raiffa, H., Decision with Multiple Objectives, Cambridge University Press, 1993.

10. Kumar, A., Antony, J., and Dhakar, T. S., Integrating Quality Function Deployment and Benchmarking to Achieve Higher Profitability, Benchmarking: An International Journal, 13 (3), 2006, pp. 290-310.

11. Lin, S., and Wei, C., A Study on the Linear Programming in Time Cost Analysis of Product Improve Design-a Focus on Computer Mouse Products, Journal of American Academy of Business, 7(2), 2005, pp. 182-186.

12. Locascio, A., and Thurston, D. L., Transforming the House of Quality to a Multiobjective Optimization Formulation, Structural Optimization, 16, 1998, pp. 136-146.
13. Raiffa, H., Preferences for Multi-Attributed Alternatives, Journal of Multi-Criteria Decision Analysis, 14, 2006, pp. 115-157.

14. Rosyidi, C. N., Irianto, D., Cakravastia, A., and Toha, I. S., Utility Based Optimization Model for Deriving Optimum Target of Functional Requirements, Proceedings of Asia Pacific Industrial Engineering and Management Systems Conference, 2008.

15. Scott, M. J., Utility Methods in Engineering Design, in Nikolaidis, E., and Ghiocel, D. (ed), CRC Handbook on Reliability Design (CRC Press), 2004.

16. Suh, N. P., Axiomatic Design Advances and Applications, Oxford University Press, 2001.

17. Takai, S., and Ishii, K., Setting Target Product Requirements: Decision Analytic Approach, Proceedings of DETC'02, ASME 2002 Design Engineering Technical Conferences and Computers and Information in Engineering Conference, Montreal, Canada, 2002.

18. Thevenot, H. J., Steva, E. D., Okudan, G. E., and Simpson T. W., A Multiattribute Theory-Based Method for Product Line Selection, Journal of Mechanical Design, 129, 2007, pp. 1179-1184.

19. van De Poel, I., Methodological Problems in QFD and Directions for Future Development, Research in Engineering Design, 18, 2007, pp. 21-36.

20. Yang, Y. S., Jang, B. S., Yeun, Y. S., and Lee,K. Y., Quality Function Deployment-Based Optimization and Exploration for Ambiguity, Journal of Engineering Design, 14, 2003, pp. 83-114.

21. Yeh, J., Shih, W., and Lin, B. H., Prototyping a Negotiation Support System for New Product Development, Journal of Chinese Institute of Industrial Engineers, 22(3), 2005, pp. 252-261. 